Diane M. Dunn • Tomoaki Ishigami • James Pankow

Andrew von Niederhausern - Jonathan Alder

Steven C. Hunt • Mark F. Leppert • Jean-Marc Lalouel

Robert B. Weiss

\title{
Common variant of human NEDD4L activates a cryptic splice site to form a frameshifted transcript
}

Received: September 9, 2002 / Accepted: October 2, 2002

\begin{abstract}
The ubiquitin ligase $N E D D 4 L$ is a candidate gene for essential hypertension on both functional and genetic grounds. By targeting the epithelial sodium channel $(\mathrm{ENaC})$ for degradation, $\mathrm{NEDD} 4 \mathrm{~L}$ is a significant determinant of sodium reabsorption in the distal nephron. Genetic linkage has been reported to a region of chromosome $18 \mathrm{q}$ harboring the gene, with phenotypes that include a rare orthostatic hypotension disorder, essential hypertension, and postural change in systolic blood pressure. A systematic search for genetic polymorphisms by resequencing exons and intron boundaries in 48 Caucasians yielded 38 variants. Among these, variant 13 is common, with either G $(70 \%)$ or A $(30 \%)$ as the last nucleotide of a putative exon 1 . This mutation could affect the generation of a previously unrecognized splice isoform. In subsequent experiments, (1) we confirmed the presence of this putative isoform in both kidney and adrenals; (2) we established that variant 13-A leads to the systematic use of an alternative splice site, generating a transcript encoding a nonfunctional protein; and (3) we demonstrated differences in tissue-specific expression of the novel isoform relative to its previously
\end{abstract}

D.M. Dunn · T. Ishigami - A. von Niederhausern - J. Alder ·

M.F. Leppert · J.-M. Lalouel · R.B. Weiss $(\bowtie)$

Department of Human Genetics, Rm 308 BPRB, 20 South 2030

East, University of Utah, Salt Lake City, UT 84112, USA

Tel. +1-801-585-5606; Fax +1-801-585-7177

e-mail: bob.weiss@genetics.utah.edu

J. Pankow

Division of Epidemiology, School of Public Health, University of Minnesota, Minneapolis, MN, USA

S.C. Hunt

Cardiovascular Genetics Research Clinic, Department of Internal Medicine, University of Utah, Salt Lake City, UT, USA

The first two authors contributed equally to this work.

A 5' exon containing the initiation codon for the NEDD4L isoform II (AB071179) is present in the human genome assembly Build 30 from the National Center for Biotechnology Information (NCBI; UCSC version hg12). This assembly was produced at NCBI based on sequence information submitted into GenBank as of June 28, 2002. This $5^{\prime}$ exon is located $121 \mathrm{~kb}$ upstream of exon 2. SNP data has been deposited in dbSNP at NCBI (ss ASSAY ID: ss 5604308 to ss 5604345). reported counterpart. Variant 13-A precludes the formation of a transcript encoding a full-length $\mathrm{Ca}^{2+}$-dependent lipid-binding $(\mathrm{C} 2)$ domain with very high evolutionary conservation among $N E D D 4 L$ orthologs. A similar $\mathrm{C} 2$ domain in the paralogous $N E D D 4$ gene plays a significant role in the transfer of its product to the apical membrane of epithelial cells. Differential function of NEDD4L isoforms could prove significant in blood pressure regulation through an effect on ENaC-dependent sodium reabsorption.

Key words NEDD4L · Hypertension - Common variants · Aberrant splicing $\cdot$ Kidney

\section{Introduction}

Genetic determinants of essential hypertension have proven elusive, as no single common variant is likely to exert a major effect on blood pressure (Corvol et al. 1999; Luft 2000). In rare Mendelian syndromes of hypertension, in contrast, gain- or loss-of-function mutations account for the physiology and the molecular basis of disorders. Such remarkable advances have pinpointed critical elements of regulatory pathways involved in sodium homeostasis and blood pressure control (Lifton et al. 2001). Thus, in Liddle's syndrome (Liddle et al. 1963), mutations affecting PPxY (PY) domains of the epithelial sodium channel (ENaC) lead to increased sodium reabsorption as a result of increased ENaC activity (Schild et al. 1995; Shimkets et al. 1994). $\mathrm{ENaC}$ mediates sodium reabsorption in the cortical collecting tubules of the kidney, accounting for the fine regulation of sodium balance. The cell surface expression of ENaC is regulated by hormones such as aldosterone and vasopressin and by intracellular signaling, including ubiquitination and phosphorylation (Debonneville et al. 2001a; Snyder et al. 2002).

The members of the Nedd4/Rsp5 protein family have a unique modular structure consisting of an $\mathrm{N}$-terminal $\mathrm{Ca}^{2+}$ dependent lipid-binding (C2) domain, multiple WW protein-protein interaction domains, and an E3 ubiquitin ligase 
HECT domain. The WW domains of the NEDD4 family of ubiquitin ligases specifically interact with the PY domains in $\mathrm{ENaC}$ subunits, leading to monoubiquitination of $\mathrm{ENaC}$ and down-regulation via endocytosis from the plasmid membrane. The vesicles carrying $\mathrm{ENaC}$ enter the vacuolar protein sorting pathway leading to recycling to the plasma membrane or targeting to lysosome for degradation (Lemmon and Traub 2000). There are two Nedd4 paralogs in human: NEDD4 (chromosome 15q, GenBank LocusID 4734) and NEDD4L (chromosome 18q21, GenBank LocusID 23327). Although NEDD4 orthologs were originally identified as $\mathrm{ENaC}$ binding partners using yeast two-hybrid experiments (Staub et al. 1996), it has recently been established that NEDD4L orthologs (also termed human, mouse Nedd4-2 proteins) are more potent regulators of $\mathrm{ENaC}$ than are NEDD4 orthologs (Harvey et al. 2001b; Kamynina et al. 2001a, 2001b).

Suggestive linkage in a region of human chromosome $18 \mathrm{q}$ has been reported for essential hypertension (Atwood et al. 2001) and postural change in systolic blood pressure (Pankow et al. 2000). Significant linkage has also been published for essential hypertension (Kristjansson et al. 2002) and orthostatic hypotensive disorder (DeStefano et al. 1998) in the vicinity of the peaks of these other reports. This general region includes the ubiquitin ligase NEDD4L (GenBank LocusID 23327). It follows that NEDD4L is a candidate gene for susceptibility to hypertensive and hypotensive disorders on both functional and genetic grounds. Because the gene may span more than $300 \mathrm{~kb}$, our systematic search for polymorphisms by resequencing was limited to exons and their splice junctions. Sequence alignments based on the comparative analysis of the human genomic $N E D D 4 L$ sequence with cDNA sequences from several organisms suggested the existence of putative exons upstream of the previously reported mammalian NEDD4L transcripts that, in apparent contrast with NEDD4, lack an intact amino-terminal C2 domain (Harvey et al. 2001a; Kamynina et al. 2001a, 2001b). A resequencing survey including these putative exons revealed 38 polymorphisms. Among these, a common variant (allelic frequency of $30 \%$ in Caucasians) at the splice junction of a putative exon 1 disrupts the formation of a transcript capable of producing a NEDD4L protein containing a conserved $\mathrm{C} 2$ domain. Characterization of the $5^{\prime}$ end of NEDD4L transcripts reveals multiple transcriptional isoforms that contain or lack this $\mathrm{C} 2$ domain. These isoforms exhibit significant differences in their tissue-specific distribution.

These novel observations may be of major significance for the function of NEDD4L. The presence of a $\mathrm{Ca}^{2+}$. dependent $\mathrm{C} 2$ domain in previously unreported isoforms of the mammalian gene may be of critical relevance for its regulated targeting in microdomains of the cell membrane, where it may interact with $\mathrm{ENaC}$ to affect its residence time at the cell surface (Plant et al. 2000), or, alternatively, may play a role in the budding of enveloped viruses (Strack et al. 2000) or in viral latency (Winberg et al. 2000). The common variant observed, markedly biasing the representation and subcellular targeting of NEDD4L isoforms, would have a major impact on these cellular functions.

\section{Materials and methods}

Sequence analysis

Genomic, cDNA, and expressed sequence tag (EST) databases included GenBank nr, Human and Mouse EST entries, the human genome draft assembly hg8 06 Aug 2001 freeze (http://genome.ucsc.edu), the mouse phusion and arachne draft assembly (http://mouse.ensembl.org), and the Fugu rubripes draft genome assembly 1 (http:// www.jgi.doe.gov/fugu/index.html). Results from BLAST and cross_match analysis were parsed with Perl scripts that iterated the sequence search to form a consistent assembly of EST, cDNA, and genomic sequence. Inclusion of EST and cDNA sequence into the assembly required at least one confirmed splice junction on genomic DNA. All genomic coordinates are referenced to the chromosome 18 draft assembly hg8 06 Aug 2001 freeze. The coordinates are reported locally, indexed to base 65000000 in that assembly.

\section{Genomic DNA used for polymorphism analysis}

The HyperGEN network recruited hypertensive sibpairs and normotensive controls for the investigation of genetic linkage to a wide variety of phenotypes (Williams et al. 2000). DNA samples were selected from 48 normotensive controls for this survey of common polymorphisms.

\section{Search for polymorphisms by resequencing}

Polymerase chain reaction (PCR) amplification was carried out in 50- $\mu$ l reaction volumes using Expand Long Template PCR System (Roche, Indianapolis, IN, USA); see Appendix, Table 1 data for primer sequences. Each reaction contained $100 \mathrm{ng}$ of genomic DNA, $350 \mu \mathrm{M}$ deoxyribonucleoside triphosphates (dNTPs), $0.2 \mu \mathrm{M}$ of each PCR primer, $1 \mathrm{X}$ reaction buffer \#2, and $2.6 \mathrm{U}$ of Taq/ Pwo polymerase mix. Cycling conditions included an initial denaturation at $94^{\circ} \mathrm{C}$ for $2 \mathrm{~min}, 10$ cycles of $94^{\circ} \mathrm{C}$ for $10 \mathrm{~s}$, $55^{\circ} \mathrm{C}$ for $10 \mathrm{~s}$, and $68^{\circ} \mathrm{C}$ for $2 \mathrm{~min}$, followed by 20 cycles of $94^{\circ} \mathrm{C}$ for $10 \mathrm{~s}, 55^{\circ} \mathrm{C}$ for $10 \mathrm{~s}$, and $68^{\circ} \mathrm{C}$ for $2 \mathrm{~min}+20 \mathrm{~s} /$ cycle. Residual primers and dNTPs were removed from PCR products with a Millipore glass fiber filter. The sequenceready templates were eluted in $70 \mu \mathrm{l}$ of sterile water. Five microliters of each template was aliquoted to a 384-well sequence dish and evaporated to dryness in a speed-vac.

Cycle sequencing was carried out in 2- $\mu \mathrm{l}$ reaction volumes using ABI BigDye Terminator v.3.0 chemistry (ABI, Foster City, CA, USA). Cycling conditions included an initial denaturation at $96^{\circ} \mathrm{C}$ for $30 \mathrm{~s}$, followed by 45 cycles of $96^{\circ} \mathrm{C}$ for $10 \mathrm{~s}, 50^{\circ} \mathrm{C}$ for $5 \mathrm{~s}$, and $60^{\circ} \mathrm{C}$ for $4 \mathrm{~min}$. On completion of cycle sequencing, $8 \mu \mathrm{l}$ of $62.5 \%$ ethyl alcohol $/ 1 \mathrm{M}$ potassium acetate, $\mathrm{pH} 4.5$, was added to each reaction and the sequence plates were centrifuged at $4000 \mathrm{rpm}$ at $4{ }^{\circ} \mathrm{C}$ for $45 \mathrm{~min}$. The samples were resuspended in $10 \mu \mathrm{l}$ of formamide and electrophoresed on an ABI 3700 DNA analyzer $(\mathrm{ABI})$ prepared with a POP-5 capillary gel matrix. 
Sequence trace files were evaluated using the Phred, Phrap, and Consed programs (Ewing et al. 1998). Potential heterozygotes were identified by using the PolyPhred version 3.5 program (Nickerson et al. 1997). Polymorphisms were verified by manual evaluation of the individual sequence traces.

Reverse transcription-PCR (RT-PCR) and rapid amplification of cDNA ends (RACE)

5' RACE reactions were performed with the SMART II RACE cDNA amplification kit (Clontech, Palo Alto, CA, USA) according to the manufacturer's protocol. Total RNA was purchased from Clontech (Catalog numbers 64096-1, 64097-1) and Stratagene (Cedar Creek, CA, USA; Catalog numbers 735014, 735474). First-strand cDNA synthesis was performed with PowerScript reverse transcriptase (Clontech) on $1 \mu \mathrm{g}$ of total RNA using the $5^{\prime}$ RACE (Clontech) primer and the addition of SMART II A oligonucleotide (Clontech). Following reverse transcription, the first-stand cDNA was used directly in 5' RACE or RT-PCR reactions. Gene-specific PCR products were obtained by using a nested PCR strategy (see Appendix, Table 2 for primer sequences). Products were subcloned into pCR2.1 with the TA Cloning Kit (Invitrogen, Carlsbad, CA, USA). Standard plasmid sequencing procedures were performed on the subclones, and RT-PCR templates were also sequenced directly.

\section{Quantitative analysis of mRNA}

Human kidney, adrenal gland, and liver mRNA, purchased from Clontech, were used for quantitative analysis of mRNA. First-strand cDNA for $1 \mu \mathrm{g}$ total RNA was prepared using reverse transcriptase (Power Script Reverse Transcriptase, Clontech) by following the manufacturer's standard protocol. Quantitative real-time PCR (Q-PCR) was performed by monitoring the fluorescence of SYBR Green (Molecular Probes, Eugene, OR, USA) with the ABI PRISM 7700 sequence detection system (Applied Biosystems). Oligonucleotide primers were designed to span at least one intron and to minimize primer-dimer formation. PCR reaction products were electrophoresed to verify specific amplification and the absence of primerdimer formation. All PCR reactions were performed in triplicate with primers that were specific for the corresponding human genes and spanned at least one intron: $5^{\prime}$ cct aaa tga gac gtc tcg cat ttg ag $3^{\prime}$ (human N4L Ex1 up), 5' agc tgg cgg aga cca gga ttt $3^{\prime}$ (human NEDD44L Ex2a UP), 5' ccg cta cgt aca atg aaa gtt tca c $3^{\prime}$ (human NEDD4L Ex3 RP), 5' gaa ggt gaa ggt cgg agt c $3^{\prime}$ (human glyceraldehyde-3-phosphate dehydrogenase [hGAPDH] UP), $5^{\prime}$ gaa gat ggt gat ggg att tc $3^{\prime}$ (hGAPDH RP). Amplification was performed during 35 cycles of $94^{\circ} \mathrm{C}$ for $10 \mathrm{~s}, 60^{\circ} \mathrm{C}$ for $10 \mathrm{~s}$, and $72^{\circ} \mathrm{C}$ for $20 \mathrm{~s}$. Water and genomic DNA served as negative controls. Cloned human cDNAs were used to generate standard curves. Expression of both exon 1-2-3 isoform and exon 2a-3 isoform was relative to hGAPDH expression.

\section{Results}

Polymorphism discovery in NEDD4L

Genomic resequencing targets were defined by a detailed analysis of the available NEDD4L (18q21) genomic sequence. KIAA0439 (GenBank accession no. AB007899) is a random full-length human cDNA sequence that maps to the NEDD4L locus on 18q21. It was shown that the predicted translation product of KIAA0439 is more similar to the Xenopus NEDD4 transcript, AJ000085 (Rebhun and Pratt 1998), than to human (15q), mouse, or rat NEDD4 transcripts (Harvey et al. 2001b). Human NEDD4 (15q) and NEDD4L (18q21) are thus paralogs, and the paralogous split preceded the divergence of the mammalianamphibian vertebrate lineages. Protein domain analysis of Xenopus NEDD4 AJ000085 indicates the presence of an evolutionarily conserved $\mathrm{C} 2$ domain, in contrast to the human NEDD4L transcript defined by KIAA0439, which contains only a partial C2 domain sequence that is appended to a $5^{\prime}$ sequence lacking an initiating methionine codon. To search for undetected $5^{\prime}$ genomic exons that may contain the missing evolutionarily conserved $\mathrm{C} 2$ domain sequence, we used the Xenopus NEDD4 AJ000085 C2 domain sequence as a translated query in a TBLASTN analysis of human 18q21 genomic sequence. Putative exons 1 and 2 are predicted from the TBLASTN alignments, and they are located $152 \mathrm{~kb}$ and $136 \mathrm{~kb}$ upstream of exon 3 , respectively. The TBLASTN analysis of exons 1 and 2 is confirmed by EST sequences BF965237 and BF678906. Exon 3 is predicted to begin the partial $\mathrm{C} 2$ domain sequence observed in KIAA0439, and genomic cDNA alignment predicts an exon $2 \mathrm{a}$, located $92 \mathrm{~kb}$ upstream of exon 3 , that corresponds to the $5^{\prime}$ sequence found in KIAA0439. The location of the predicted $N E D D 4 L$ exon - intron junctions and the genomic target coordinates for resequencing are in Table 1.

Common variants of $N E D D 4 L$ were discovered by sequencing PCR products spanning exons $1,2,2 \mathrm{a}$, and 3 through 31 from 48 unrelated individuals. We surveyed 5524 nucleotides in exons, and 23108 nucleotides overall, for polymorphisms by resequencing. Table 2 shows the position, alleles, allele frequency, and functional implication of the 34 single nucleotide and 4 insertion/deletion polymorphisms detected. One polymorphism, variant 13 at nucleotide 82723 , occurred at the last nucleotide of exon 1 and is common in Caucasians ( $70 \% \mathrm{G}, 30 \% \mathrm{~A})$. This variant has the potential to disrupt exon 1 splicing because $\mathrm{G}$ is the most common nucleotide at this position in consensus $5^{\prime}$ splice donor sites (Stephens and Schneider 1992). Variants in this position are known to alter splice site selection in numerous human mutations (Nakai and Sakamoto 1994; Rogan et al. 1998). This prompted us to evaluate the effect of variant 13 on exon 1 splice site selection in human kidney and adrenal RNA. 
Table 1. Summary of NEDD4L genomic resequencing targets and exon coordinates

\begin{tabular}{lcccllr}
\hline Resequencing target & & & \multicolumn{3}{l}{ Exon coordinates } & \\
\hline Begin & End & Length (nt.) & Exon & Begin & End & Length (nt.) \\
80827 & 82835 & 2008 & 1 & 82481 & 82723 & 242 \\
98708 & 99315 & 607 & 2 & 98954 & 99027 & 73 \\
127963 & 128583 & 630 & $2 \mathrm{a}$ & 143659 & 143902 & 243 \\
234613 & 235239 & 626 & 3 & 234885 & 234966 & 81 \\
238062 & 238691 & 629 & 4 & 238357 & 238395 & 38 \\
241163 & 241797 & 634 & 5 & 241459 & 241512 & 53 \\
305150 & 305786 & 636 & 6 & 305439 & 305489 & 50 \\
311752 & 312995 & 1243 & 7 & 311882 & 311943 & 61 \\
& & & 8 & 312689 & 312791 & 102 \\
314181 & 314805 & 624 & 9 & 314453 & 314619 & 166 \\
318155 & 318757 & 602 & 10 & 318452 & 318584 & 132 \\
319956 & 320592 & 636 & 11 & 320195 & 320371 & 176 \\
323037 & 323666 & 629 & 12 & 323275 & 323349 & 74 \\
324733 & 325219 & 486 & 13 & 324935 & 324994 & 59 \\
330241 & 331513 & 1272 & 14 & 330495 & 330626 & 131 \\
332149 & 332780 & 631 & 15 & 331135 & 331254 & 119 \\
338719 & 339341 & 662 & 16 & 332363 & 332560 & 197 \\
340213 & 340849 & 636 & 17 & 338994 & 339071 & 77 \\
346361 & 346992 & 631 & 18 & 340448 & 340592 & 54 \\
353435 & 345067 & 632 & 19 & 346651 & 346709 & 58 \\
355258 & 355899 & 641 & 20 & 353725 & 353790 & 65 \\
356971 & 357592 & 621 & 21 & 355456 & 355685 & 229 \\
359495 & 360059 & 564 & 22 & 357293 & 357324 & 121 \\
362367 & 362997 & 630 & 23 & 359854 & 359924 & 70 \\
372427 & 373048 & 621 & 24 & 362631 & 362726 & 95 \\
374717 & 375346 & 629 & 25 & 372703 & 372776 & 73 \\
376607 & 377237 & 630 & 26 & 374983 & 375043 & 60 \\
378280 & 378918 & 638 & 27 & 376896 & 376955 & 59 \\
379855 & 380491 & 636 & 28 & 378542 & 378649 & 107 \\
380678 & 381313 & 635 & 29 & 380103 & 380199 & 96 \\
385395 & 387844 & 2449 & 30 & 380944 & 381016 & 72 \\
& Total: $23108 \mathrm{nt}$. & 31 & 385624 & 387615 & 1991 \\
\hline & & & & & $5224 \mathrm{nt}$. & \\
\hline
\end{tabular}

nt., Nucleotide

${ }^{a}$ Begin and end coordinates are from the human genome draft assembly hg8 06 Aug 2001 freeze (www.genome.ucsc.edu, University of California, Santa Cruz). The table coordinates can be indexed to the chromosome $18 \mathrm{hg} 8 \mathrm{draft}$ coordinates by adding 65000000 to each value. The resequencing target is the number of base pairs covered by high quality (phrap $>=20$ ) sequence

\section{Transcript analysis by RT-PCR, RACE, and Q-PCR}

RT-PCR analysis was performed on human kidney and adrenal RNA preparations with exon 1- and exon 3-specific primers. Two sources of RNA from each tissue were used: kidney $($ source 1$)=$ normal, whole kidneys pooled from 6 male/female Caucasians; kidney (source 2 ) = two female donors; adrenal (source 1$)=$ normal, whole adrenal glands pooled from 62 male/female Caucasians; adrenal (source 2) $=$ one female. Direct sequencing of RT-PCR products from kidney RNA displayed a mixture of sequences beginning at the exon 1-2 junction; therefore, the products were subcloned into a plasmid vector, and independent transformants were sequenced. Figure 1 shows that two distinct exon 1-2 splice junctions were found: splice product 1 corresponds to the predicted sequence of exon 1 , with variant 13 as the last exon 1 nucleotide, whereas splice product 2 is generated by splicing $10 \mathrm{nt} 3^{\prime}$ of variant 13 , and results in a transcript that disrupts the predicted $\mathrm{C} 2$ domain translated reading frame. The variant $13 \mathrm{G}$ allele displays leaky splice site selection with a mixture of splice product $1(35 / 51$ in kidney, 11/20 in adrenal) and splice product $2(16 / 51$ in kidney, 9/20 in adrenal), whereas the variant $13 \mathrm{~A}$ allele is detected only in splice product 2 (87/87 in kidney and adrenal).

Further characterization of the representation and semiquantitative abundance of $5^{\prime}$ splice isoforms were performed with 5' RACE reactions with primers specific for exons 2, 2a, 2c, and 3, using the same RNA preparations used in the RT-PCR analysis. RACE products were subcloned into a plasmid vector and 96 clones were sequenced for each RACE reaction. Figure 2 shows the exon structure of the RACE products and the number of unique $5^{\prime}$ ends seen with each primer. Exon 3 RACE primers generated products corresponding to the exon 1-2-3 product (isoform I) that were similar to the exon 1-3 RT-PCR products, exon $2 \mathrm{a}-3$ products (isoform III) that were similar to the KIAA0439 transcript, and exon 2a-2d-3 and exon 2b-3 products. Only exon 1-containing forms have a potential initiating methionine codon upstream of exon 3. Using RACE primers within exon 2, approximately $50 \%$ of the subcloned RACE products from kidney and adrenal showed splicing to exon 1 . The exon 1-2 splice junction for RACE clones containing the $\mathrm{G}$ allele of variant 13 were 
Table 2. SNP discovery in human NEDD4L exons and intron flanks

\begin{tabular}{|c|c|c|c|c|}
\hline Variant & Coordinate $^{\mathrm{a}}$ & Implication & Alleles & Frequency \\
\hline 1 & 80950 & 5' Flank & $\mathrm{T} / \mathrm{C}$ & 0.16 \\
\hline 2 & 80986 & 5' Flank & $\mathrm{C} / \mathrm{G}$ & 0.01 \\
\hline 3 & 81117 & $5^{\prime}$ Flank & $\mathrm{C} / \mathrm{A}$ & 0.47 \\
\hline 4 & 81144 & $5^{\prime}$ Flank & $\mathrm{G} / \mathrm{A}$ & 0.27 \\
\hline 5 & 81189 & $5^{\prime}$ Flank & $\mathrm{A} / \mathrm{G}$ & 0.22 \\
\hline 6 & 81479 & $5^{\prime}$ Flank & $\mathrm{C} /-$ & 0.47 \\
\hline 7 & 81543 & $5^{\prime}$ Flank & $\mathrm{C} / \mathrm{T}$ & 0.32 \\
\hline 8 & 81756 & 5' Flank & G/A & 0.49 \\
\hline 9 & 82261 & $5^{\prime}$ Flank & G/A & 0.31 \\
\hline 10 & 82369 & $5^{\prime}$ Flank & $\mathrm{A} / \mathrm{G}$ & 0.21 \\
\hline 11 & 82541 & $5^{\prime}$ Flank & G/A & 0.01 \\
\hline 12 & 82578 & $5^{\prime}$ Flank & G/A & 0.01 \\
\hline 13 & 82723 & Splice junction & G/A & 0.30 \\
\hline 14 & 98767 & Intron 1 & $\mathrm{~A} / \mathrm{G}$ & 0.01 \\
\hline 15 & 98830 & Intron 1 & $\mathrm{C} / \mathrm{T}$ & 0.50 \\
\hline 16 & 142069 & Intron 2 & $\mathrm{G} / \mathrm{A}$ & 0.01 \\
\hline 17 & 142182 & Intron 2 & $\mathrm{C} / \mathrm{T}$ & 0.01 \\
\hline 18 & 142210 & Intron 2 & $\mathrm{~A} / \mathrm{C}$ & 0.24 \\
\hline 19 & 143720 & Exon2a & $\mathrm{C} / \mathrm{T}$ & 0.01 \\
\hline 20 & 143784 & Exon2a & G/A & 0.22 \\
\hline 21 & 238195 & Intron 3 & $\mathrm{C} / \mathrm{G}$ & 0.06 \\
\hline 22 & 305555 & Intron 6 & $\mathrm{~T} / \mathrm{C}$ & 0.44 \\
\hline 23 & 305589 & Intron 6 & $\mathrm{~A} / \mathrm{G}$ & 0.19 \\
\hline 24 & 318797 & Intron 10 & $\mathrm{C} / \mathrm{T}$ & 0.38 \\
\hline 25 & 320155 & Intron 10 & TTCT/- & 0.22 \\
\hline 26 & 330373 & Intron 13 & G/A & 0.42 \\
\hline 27 & 331039 & Intron 14 & $\mathrm{~T} / \mathrm{C}$ & 0.01 \\
\hline 28 & 331053 & Intron 14 & GTT/- & 0.24 \\
\hline 29 & 339121 & Intron 17 & $\mathrm{~A} / \mathrm{C}$ & 0.01 \\
\hline 30 & 359469 & Intron 22 & G/A & 0.02 \\
\hline 31 & 359494 & Intron 22 & G/A & 0.22 \\
\hline 32 & 359713 & Intron 22 & $\mathrm{~T} / \mathrm{C}$ & 0.17 \\
\hline 33 & 360074 & Intron 23 & $\mathrm{~A} / \mathrm{G}$ & 0.21 \\
\hline 34 & 362468 & Intron 23 & TTAAA/- & 0.41 \\
\hline 35 & 362874 & Intron 24 & $\mathrm{C} / \mathrm{T}$ & 0.04 \\
\hline 36 & 375143 & Intron 26 & $\mathrm{G} / \mathrm{C}$ & 0.01 \\
\hline 37 & 378727 & Intron 28 & G/A & 0.01 \\
\hline 38 & 386046 & 3' UTR & $\mathrm{T} / \mathrm{C}$ & 0.05 \\
\hline
\end{tabular}

SNP, Single-nucleotide polymorphism; UTR, untranslated region ${ }^{a}$ Coordinates are from the human genome draft assembly hg8 06 Aug 2001 freeze (www.genome.ucsc.edu, University of California, Santa Cruz). The table coordinates can be indexed to the chromosome $18 \mathrm{hg} 8$ draft coordinates by adding 65000000 to each value

either splice product 1 or splice product 2 , and only splice product 2 was seen when the A allele was present, similar to the results of RT-PCR analysis. The other RACE products terminated in exon 2 or spliced to unaligned genomic sequence. Race experiments with both exon $2 \mathrm{a}$ and $2 \mathrm{c}$ primers resulted in no detectable $5^{\prime}$ sequence spliced to these exons, implying that these exons may be adjacent to promoters expressed in these tissues. RACE experiments with exon 3 primers confirmed the presence of the isoform I transcript and the isoform III transcript. These experiments also revealed two distinct exons expressed in kidney: $2 \mathrm{~b}$ and $2 \mathrm{~d}$, with $2 \mathrm{~b}$ represented as a $5^{\prime}$ exon without an in-frame AUG codon spliced to exon 3 , similar to exons $2 \mathrm{a}$ and $2 \mathrm{c}$, and exon $2 \mathrm{~d}$ detected as an alternative splice form consisting of exon $2 \mathrm{a}-2 \mathrm{~d}-3$, each with consensus splice sequences at their $5^{\prime}$ donor and $3^{\prime}$ acceptor sites.

The relative level and tissue-specific expression of isoform I versus the isoform III was analyzed by Q-PCR.
Figure 3 shows the results of four experiments, each in triplicate, for the quantitative analysis of NEDD4L mRNA from kidney, adrenal gland, and liver, normalized to the expression of hGAPDH in each tissue. Expression of GAPDH in these tissues is not significantly different (data not shown). Expression of isoform I is significantly higher in both kidney and adrenal than isoform III. These findings suggest that isoform I (exon 1-2-3) is expressed in a tissuespecific manner, and that it is more abundant than isoform III (exon 2a-3) in kidney and adrenal gland.

Refinement of NEDD4L predicted genomic structure and transcript isoform pattern

Figure 4A combines cDNA, EST, RT-PCR, and RACE data and suggests six different transcript isoforms spliced to exon 3. Isoforms I and II splice an in-frame AUG codon to exon 2, adding 8 and 16 amino acids, respectively. Isoform I spans $303 \mathrm{~kb}$ of genomic DNA (draft sequence with 54 gaps) and consists of 30 exons. Both isoforms are capable of producing a translated protein containing the evolutionarily conserved $\mathrm{C} 2$ domain beginning in exon 2 . The similarity of this C2 domain to consensus Simple Modular Architecture Research Tool (SMART) C2 domain sequence (Schultz et al. 2000) is shown in Fig. 4B, as well as the location of this domain across exon 2 through exon 6 of NEDD4L. The sequence $5^{\prime}$ of the exon 2 splice junction in isoform II is not represented in the current version of the draft human genome sequence, and we postulate it may reside $5^{\prime}$ of exon 1 , in an unfinished region of chromosome 18 . This isoform was not detected in the 5' RACE analysis, but is detected by RT-PCR from both kidney and adrenal RNA (data not shown).

Isoforms III and IV splice exons $2 \mathrm{a}$ and $2 \mathrm{c}$ to exon 3 , respectively. Functional studies of mammalian NEDD4L protein have used the exon $2 \mathrm{a}-3$ isoform typified by KIAA0439 (GenBank accession no. AB007899), which lacks an intact $\mathrm{N}$-terminal $\mathrm{C} 2$ domain. Neither exon 2a nor exon $2 c$ contains AUG codons in any frame, and the first AUG start codon in these isoforms occurs in exon 7. These isoforms are predicted to produce a form of NEDD4L protein that completely lacks the $\mathrm{C} 2$ domain. Isoforms $\mathrm{V}$ (exon 2a-2d-3) and VI (exon 2d-3) also lack AUG start codons and are also predicted to initiate translation in exon 7.

Analysis of mouse cDNA, EST, and draft genomic assemblies reveals conserved exon-intron junctions for exons 2, 2a, $2 \mathrm{~b}, 2 \mathrm{c}$, and 3 . Mouse exon $2 \mathrm{a}-3$ splice form is represented by the following ESTs: AW106584, BI687556, BB621848, AW228518, BI218843, AW226920, BB846219, AI527754, AI227149, AI931594, AW910412, BI690367, BG971715, BI650832, BI559036. Mouse exon 2b-3 splice isoform is represented by cDNA AK004969, and mouse exon 2c splice isoform is represented by ESTs BG404747 and BG294676. The mouse exon 2-3 splice form is represented by ESTs BB569841, BB611456, BB635343, BB639757, BB640919, BB847602, and BB863379. These seven ESTs form five sequence clusters, and two of these clusters match draft assemblies with a consensus GT dinucleotide at the predicted 5' 
Fig. 1A,B. Exon 1-exon 2 splice junctions and predicted translation (A) found from reverse transcription-polymerase chain reaction (RT-PCR) products of kidney and adrenal total RNA using exon 1 and exon 3 primers. The number of independent sequence-verified clones (B) containing either variant $13 \mathrm{G}$ or A in splice products 1 or 2 is shown for kidney and adrenal RNA preparations. The $P$ value from Fischer's exact test of whether variant 13 affects splice site selection is also shown

A.

Splice Product 1

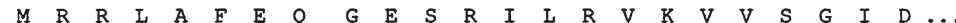

ATGAGACGTCTCGCATTTGAGCAG GGAGAGTCCCGTATTCTCAGAGTAAAAGTTGTTTCTGGAATTGA

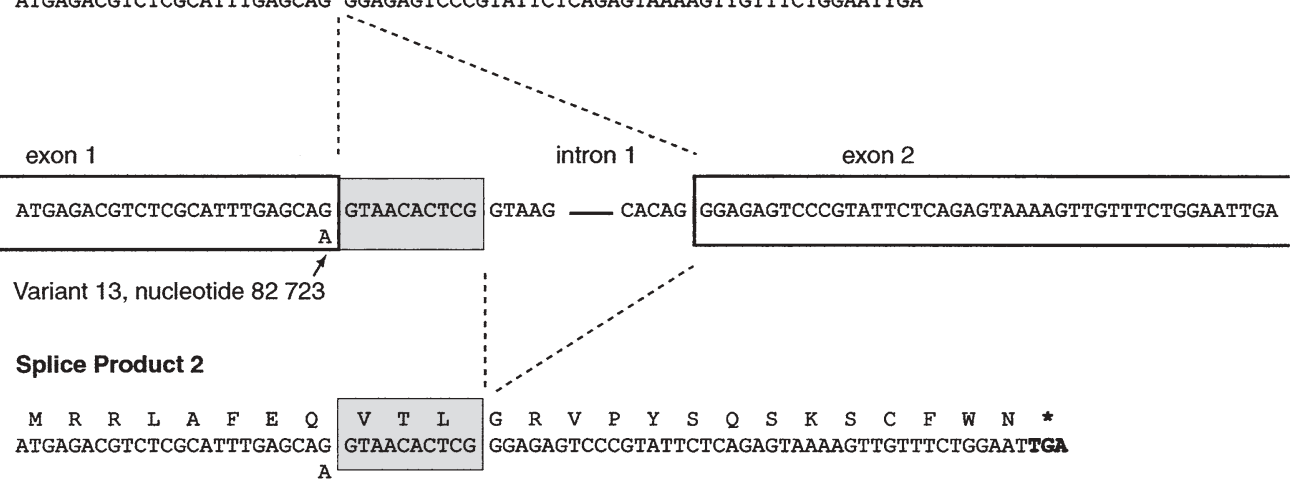

B.

Kidney

Splice Product

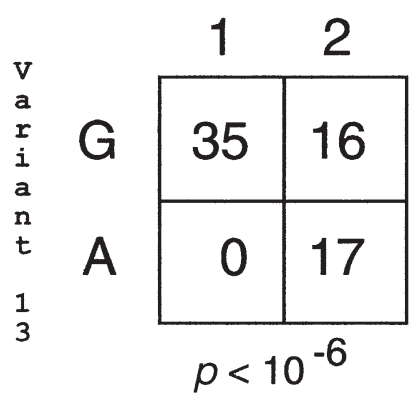

\section{Adrenal}

Splice Product

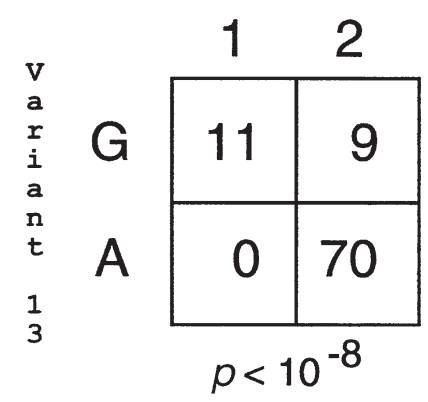

Fig. 2. 5' rapid amplification of cDNA ends ( $R A C E)$ analysis of NEDD4L in kidney and adrenal gland. The exonic start location of the most $5^{\prime}$ end for each transcript is shown, as well as the total number of clones and the number of unique $5^{\prime}$ ends found for each transcript. The exonic coordinates locate the $5^{\prime}$ end in the human genome draft assembly hg8 06 Aug 2001 freeze by addition of 65000000 bases. nt., Nucleotide
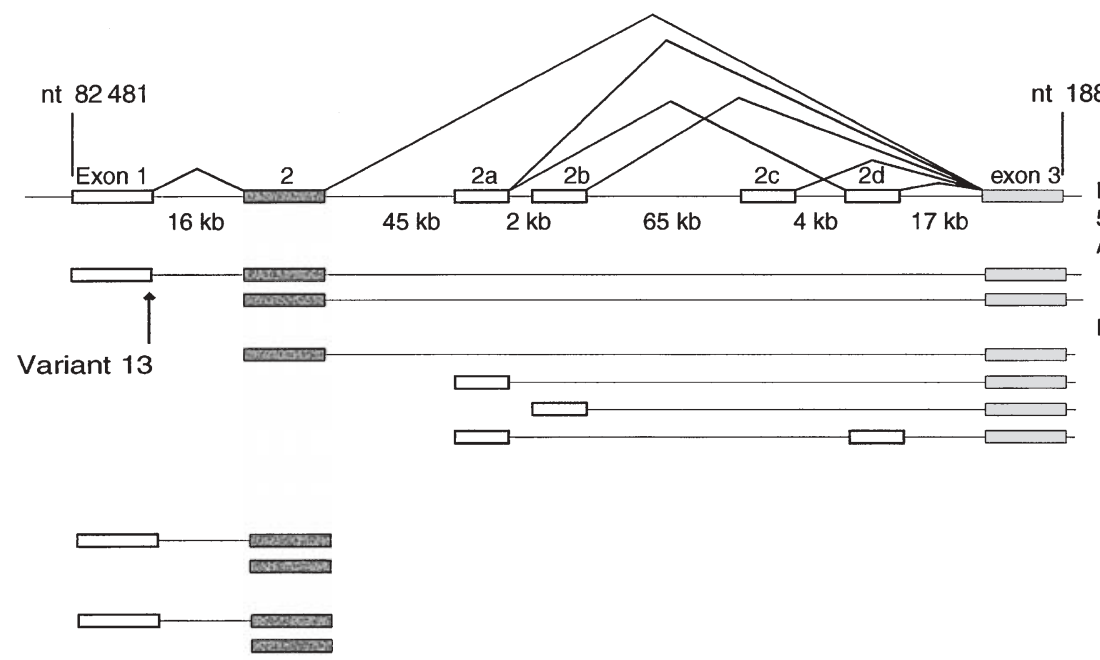

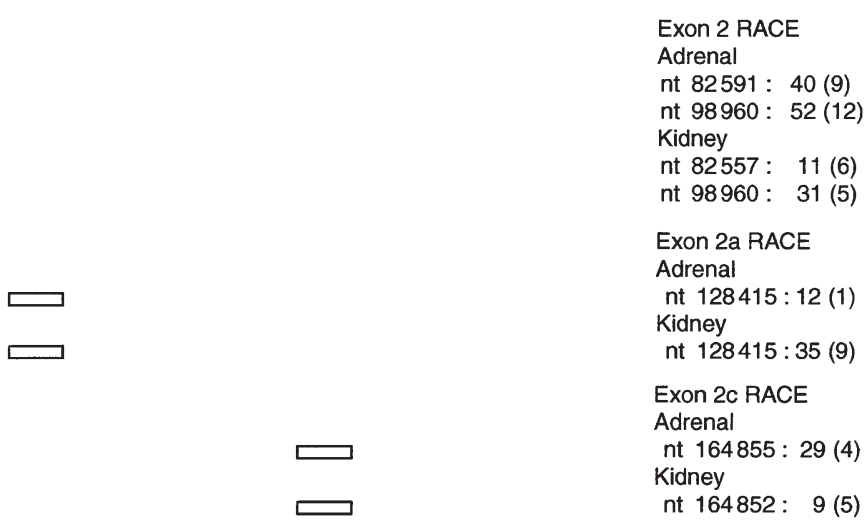


exon 1 - 2 - 3 / hGAPDH in various tissues

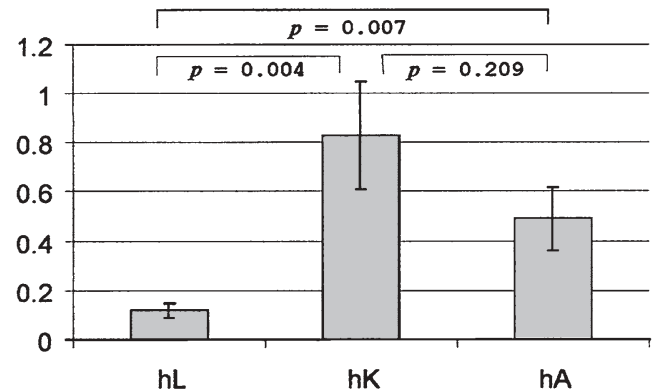

exon $2 \mathrm{a}-3 / \mathrm{hGAPDH}$ ratio in various tissues

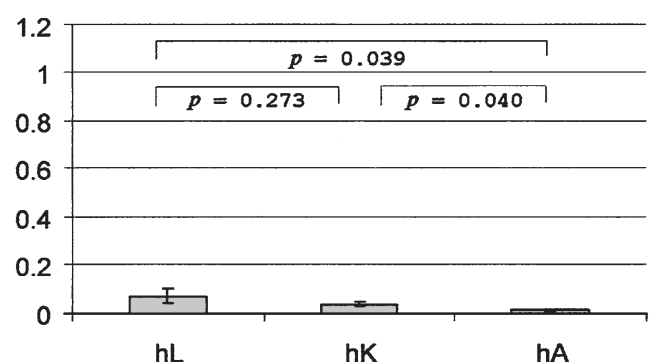

Fig. 3. Quantitative PCR analysis of exon 1-2-3 isoform I versus exon $2 \mathrm{a}$-exon 3 isoform III in human kidney $(h K)$, adrenal gland $(h A)$, and liver $(h L)$. Standard curves from a two-fold dilution series of cloned PCR target for both NEDD4L isoforms and human glyceraldehyole-3phosphate dehydrogenase $(h G A P D H)$ were used to calcuated the rela- tive ratios of NEDD4L/GAPDH. The NEDD4L/GAPDH ratios are calculated based on predicted molar amounts of target mRNA. The probability that the expression levels are significantly different is shown with $P$ values calcuated with a student's $t$-test

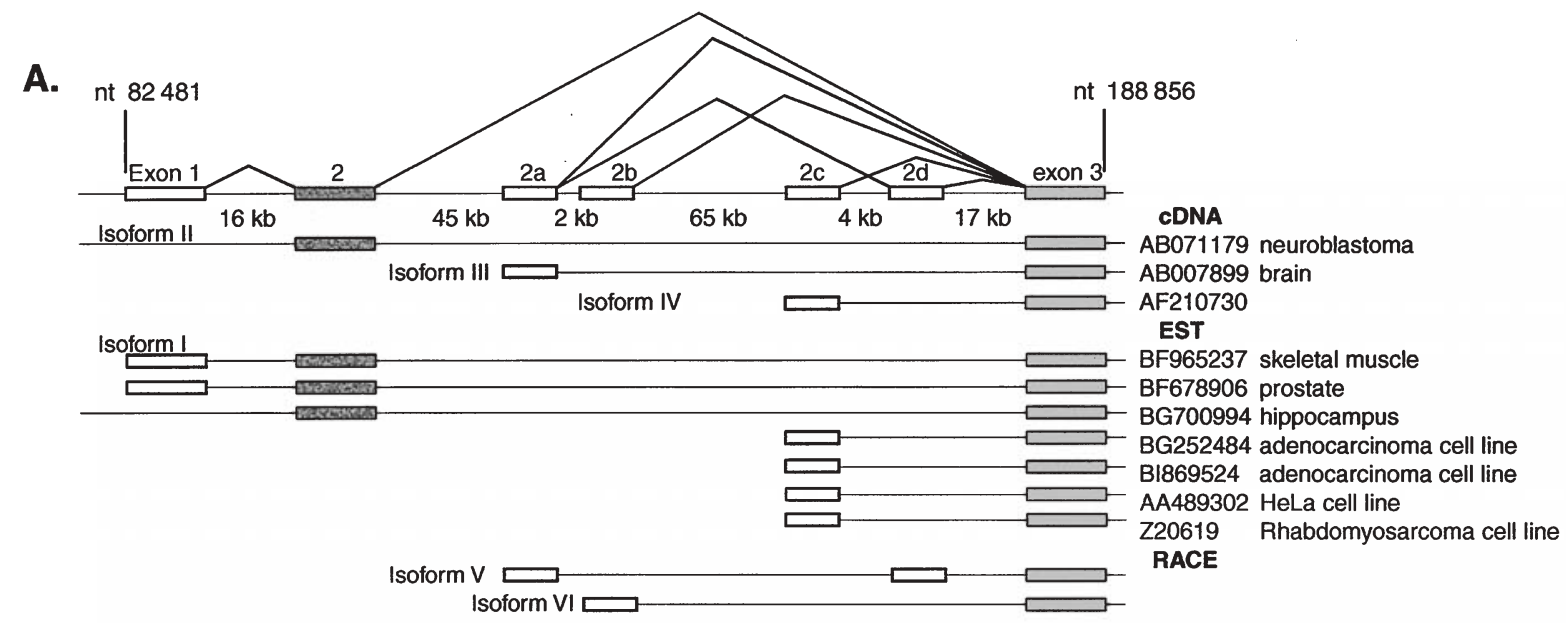

B.

SMART C2 domain TLTVKI ISARNLPPKDKG KKSDPYVVSIDGDPREK----KKTTKVVNTLNEVWNETFEFEVPPPELSELEIEVYDKDRFSRDDFIGRVTIPLSDLLLGGRH human NEDD4L C2 transcripts ILRVKVVSGIDIAKKDIFGASDPYVISIYYADENRELALVOTKTIKKTLNPKWNEE FYRVNPSNHRLL-FEVFDENRLTRDDFLGOVDVPLSHLPTEDPT

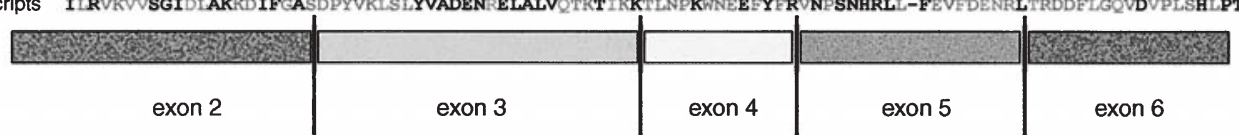

human NEDD4 C2 IVRVRVIAGIGLAKKD ILGASDPYVRVILY-DPMNGVLTSVQTKTI KKSLNPKGNEEILFRVHPQQHRLL-FEVFDENRLTRDDFLGQVDVPIYPLPTENPRM human NEDD4L C2 ILRVKVVSGIDLAKKDIFGASDPYVKLSLYVADENRELALVQTKTIKKTLNPKWNEEFYFRVNPSNHRLL-FEVFDENRLTRDDFLGQVDVPLSHLPTEDPTM mouse NEDD4L C2 ILRVKVVSGTDI_AKKDIFGASDPYVKL_SLYYVADENRELALVQTKTIKKTLNPKWNEEFYFRVNPSNHRLI-FEVFDENRLT'RDDFI/GQVDVPLSHL.PTEDPTM chicken NEDD4L C2 IIRVKVVSGIDLAKKDIFGASDPYVKLSLYVADENRELALVOTKTIKKTLNPKWNEEFYFRVNGTNHRLL-FEVFDENRLTRDDFLGOVDVPLSHLPTEDPSM Xenopus NEDD4L C2 ILRVKIVSGTDLAKKD IFGASDPYVKLSLYVADENREIALLVTKTIKKTLNPKWNEEFFFRVHPTNHRLL-FEVFDENRLIRDDELGOVDVPLNHLPTEDPTM xenOpUS NEDD4L C2 ILRVKIVSGTDLAKKDIFGASDPYVKLSLYVADENRELALVQTKTIKKTLNPKWNEEEFFRVHPTNHRLL-FEVFDENRLTRDDFLGQVDVPLNALPTEDPTM
fugu NEDD4L C2 VLRVKVIAGIDLAKKD IIGAGDPYVKLSLYVADENRELALVQTKTIKKTLNPKWNEEFFFRVSPSNHRLL-FEVEDENRLVRDDELGQVDVPLSHLPTEDPTM

MRRLAFEOGESRILRVKYVSGIDL human isoform I

MATGLGEPVYGLSEDEGESRILRVKVVSGIDL human isoform II, AB071179 translation

MAATY EPIYGLSEDEHETRVLRVKVIAGIDL Fugu exon 1 - exon 2 translation

MAAEPIYGLSEDDEESRILRVKIVSGTDL XenOPUS CAA03915

exon $1 \uparrow$ exon 2 boundary

Fig. 4A,B. Exon-intron structure of the $5^{\prime}$ end of $N E D D 4 L$ on human chromosome 18q. The exons (A) were defined by searching GenBank Human expressed sequence tag (EST) entries and nr databases with NEDD4L exon 3 as the query (CAGTGATCCGTATGTGAAACTT TCATTGTACGTAGCGGATGAGAATAGAGAACTTGCTTTGGTC CAGACAAAAACAATTAAAAAG). ESTs and cDNAs that have exons spliced 5' to exon 3 are shown. AF21730 sequence $5^{\prime}$ of exon 2 is not represented in the current draft sequence of the human genome. The sequences were compared with human genome draft assembly hg 8
06 Aug 2001 freeze to define exon-intron boundaries; all exons conformed to consensus splice sites $\left(5^{\prime}-\mathrm{AG}, 3^{\prime}-\mathrm{GT}\right)$. The exonic location and conservation of the $\mathrm{C} 2$ domain $(\mathbf{B})$ is shown for NEDD4L transcripts. The alignment of human NEDD4L is shown versus the Simple Modular Architecture Research Tool (SMART) C2 (SM0239) consensus sequence. The alignments of predicted $\mathrm{C} 2$ domains of mouse and Fugu NEDD4L orthologs, and the human NEDD4 paralog, are also shown 
splice donor site. None of these clusters displays significant similarity to human exon 1, although BB863379 does have $71 \mathrm{nt} 5^{\prime}$ of exon 2 that match the $5^{\prime}$ end of human isoform II at $89 \%$ identity. However, this EST is only $96 \%$ identical to the other mouse exon 2-3 ESTs; thus, it is likely that this EST represents a pseudogene. TBLASTN analysis of isoform I and II against the draft Fugu rubripes (puffer fish) genome revealed a draft assembly (Scaffold_826, 55kb with nine gaps) spanning $26 \mathrm{~kb}$ containing exons 2 through 30 (exons 10,11 , and 12 are missing from the assembly) and displaying conserved exon - intron junctions for the 26 exons detected. Translation of the Fugu NEDD4L exons yields a protein that is $87 \%$ identical and $94 \%$ similar to human NEDD4L isoform II.

Figure 4B shows that there are no amino acid substitutions between the predicted $\mathrm{C} 2$ domains of human and mouse NEDD4L, and that there are fewer substitutions between Xenopus, Fugu, chicken, mouse, and human NEDD4L than between human NEDD4L and NEDD4. The Fugu NEDD4L gene also contains an exon $1.2 \mathrm{~kb}$ upstream of exon 2 that is predicted to splice an in-frame AUG codon to exon 2 with the addition of $15 \mathrm{~N}$-terminal amino acids. That translated product displays detectable sequence similarity with the translated product of isoform II (Fig. 4B), which is the isoform whose sequence $5^{\prime}$ of exon 2 is missing in current human finished and draft sequence databases. Although orthologous $2 \mathrm{a}, 2 \mathrm{~b}$, and $2 \mathrm{c}$ exons are detected in the mouse draft sequence, there is no detectable similarity in Fugu NEDD4L intron 2 using either TBLASTN or BLASTN analysis. This suggests that isoform II may reflect the most ancestral form of NEDD4L, and that the sequence of the N-terminal C2 domain has been conserved by natural selection.

\section{Discussion}

This resequencing survey of NEDD4L exons and flanking introns for polymorphic variants in 48 Caucasian individuals detected 35 flanking/intronic variants, and 3 exonic variants. Variant 13-A occurs at an allele frequency of 0.30 , and its location in exon 1 results in a synonymous CAG/A glutamine codon substitution, but also changes the $5^{\prime}$ splice donor site from a strong to a weak consensus: CAG-GT to CAA-GT. Analysis of the NEDD4L exon 1-2 splice junction from RT-PCR and RACE products from human and adrenal RNA reveals leaky splice site selection, of which only one form is predicted to lead to in-frame translation of the evolutionarily conserved N-terminal C2 domain. The identity of variant 13 changes the ratio of splice site selection from preferred splicing of the in-frame product with the $G$ variant, to no detectable splicing of the in-frame product with the A variant. Numerous human mutations have been described that have G-to-A alterations at this position in $5^{\prime}$ splice donor sites (Rogan et al. 1998). Also, the human cyclin D1 (CCND1) gene contains a common G/A polymorphism at this $5^{\prime}$ splice donor site consensus position in CCND1 exon4, and this polymorphism modulates mRNA splicing to produce two transcripts (Betticher et al. 1995). This common polymorphism has recently been implicated in altering the age of onset of hereditary nonpolyposis colorectal cancer (Bala and Peltomaki 2001; Kong et al. 2000).

RT-PCR and RACE analysis from human and adrenal RNA revealed six NEDD4L transcript isoforms. Functional studies of mammalian NEDD4L protein have used a spliced form of the human NEDD4L protein typified by KIAA0439 (GenBank accession no. AB007899), which corresponds to isoform III resulting from exon $2 \mathrm{a}-3$ splicing and lacking an intact N-terminal $\mathrm{C} 2$ domain. This is in contrast to the founding, and defining, member of the NEDD4L family, a Xenopus laevis Nedd4-like protein that has an intact C2 domain (Rebhun and Pratt 1998). Our analysis of genomic, cDNA, and EST sequence reveals a conserved exon 2 in Fugu, mouse, and human that corresponds to the orthologous sequence in Xenopus. RACE analysis using exon 2 and exon 3 primers demonstrates that isoform I of human NEDD4L is an abundant 5' transcript isoform in adrenal tissue, whereas in kidney there is evidence for multiple isoforms including I, III, V, and VI. Isoforms III through VI all generate transcripts in which the first potential AUG start codon is in exon 7, distal to the $\mathrm{C} 2$ domain. RACE experiments from exon $2 \mathrm{a}$ and $2 \mathrm{c}$ did not detect any sequence spliced $5^{\prime}$ of these exons, and exon 13 RT-PCR revealed only exon 1-2-3 splice forms, with no splicing detected to exons $2 \mathrm{a}, 2 \mathrm{~b}, 2 \mathrm{c}$, or $2 \mathrm{~d}$. Therefore, isoforms containing exons $2 \mathrm{a}, 2 \mathrm{~b}, 2 \mathrm{c}$, or $2 \mathrm{~d}$ are expected to begin translation from the AUG codon in exon 7, which is the first AUG codon in these transcripts. This exon 7 AUG codon is conserved between human, mouse, chicken, Xenopus, and Fugu, and, as shown in Fig. 4B, it is located at the C-terminal junction of the C2 domain. Q-PCR analysis of isoform I versus isoform III in total RNA from human kidney, adrenal, and liver indicated tissue-specific expression patterns for isoform I, and suggested that this is an abundant isoform in kidney and adrenal. It should be pointed that not only does variant 13-A affect a previously unreported isoform of human NEDD4L, but this isoform I is also significantly more abundant in kidney and adrenal gland than the better investigated, C2-less isoform III corresponding to the KIAA0439 transcript.

The conserved NEDD4L C2 domain translated from exon 2 through exon 6 suggests that this sequence has been maintained through functional selection. The observed average amino acid identity in large-scale comparisons of orthologous mouse and human protein sequences is 85.4\% (Makalowski et al. 1996). The translated, 101 amino acid C2 domain of human NEDD4L is $100 \%$ identical to mouse $\mathrm{C} 2,98.0 \%$ identical to chicken $\mathrm{C} 2,96.0 \%$ identical to Xenopus C2, and $94.1 \%$ identical to Fugu C2 domains. This level of sequence conservation suggests that the NEDD4L C2 domain is functional and under strong selective constraints. The comparison of the $\mathrm{N}$-terminal sequence prior to the C2 domain of human isoforms I and II with Fugu and Xenopus indicates that isoform II is conserved for 9 of 16 amino acid residues at the $\mathrm{N}$ terminus (Fig. 4B). The genomic sequence corresponding to the $5^{\prime}$ end of isoform II has not yet appeared in the human genome assembly, but we can 
postulate that it may be located upstream of exon 1 of isoform I. The conserved residues at the $\mathrm{N}$ terminus of isoform II suggest it may represent the most ancestral isoform of NEDD4L, and that the isoform I promoter and exon 1 sequences may be more recently evolved. The existence of multiple isoforms that result in either $\mathrm{C} 2$ or C2-less forms of NEDD4L protein, some of which are conserved between human and mouse, suggests that these two forms may have different functional roles in ubiquitination and endocytosis of protein targets such as $\mathrm{ENaC}$, and may have evolved under different selective constraints.

Although no experiments have yet been reported with a human or mouse NEDD4L protein containing an intact $\mathrm{C} 2$ domain from either isoform I or II, there are several studies using C2-less NEDD4L and Nedd4/Rsp5 proteins in mammalian, amphibian, and yeast systems. The $\sim 110$ amino acid $\mathrm{C} 2$ domain is a eukaryotic protein module that has $\mathrm{Ca}^{2+}$-dependent interactions with phospholipids, inositol polyphosphates, and intracellular proteins. The human Nedd4 C2 domain has been shown to cause $\mathrm{Ca}^{2+}$-dependent plasma membrane localization in polarized Madin-Darby canine kidney (MDCK) cells (Plant et al. 1997). This localization of endogenous Nedd4 occurred preferably to apical and lateral membranes in these polarized cells, and heterologous expression of a $\mathrm{C} 2$ deletion construct showed that the $\mathrm{C} 2$ domain was required for $\mathrm{Ca}^{2+}$-dependent membrane localization. Further studies have shown that annexin XIIIa and $b$ are the protein-binding partners of Nedd4 in this $\mathrm{Ca}^{2+}$-dependent membrane localization assay (Plant et al. 2000). The $\mathrm{Ca}^{2+}$-dependent binding to annexin XIIIb further targets the complex to lipid rafts, which are membrane cholesterol and sphingolipid microdomains involved in endocytosis (Ikonen 2001).

Several experiments have investigated the effect of the Nedd4 C2 domain on regulation of ENaC activity. In both Xenopus oocytes and rat thyroid epithelia, removal of the Nedd4 C2 domain in expression constructs caused a stronger down-regulation of ENaC activity (Snyder et al. 2001). This result has also been seen in a comparison of human NEDD4 and NEDD4L in down-regulating ENaC activity in Xenopus oocytes (Kamynina et al. 2001a, 2001b). In this case, removal of Nedd4 $\mathrm{C} 2$ domain also resulted in stronger down-regulation of $\mathrm{ENaC}$ activity, and expression of an NEDD4L isoform III construct (KIAA0439) displayed more potent inhibition of $\mathrm{ENaC}$ than did NEDD4 constructs. These experiments also attempted to convert isoform III of NEDD4L to a C2-containing form by adding an AUG codon in-frame at the beginning of exon 2a. This construct had no effect on $\mathrm{ENaC}$ regulation in Xenopus oocytes; however, with the identification of isoform I, it is now apparent that this recombinant protein restored a truncated $\mathrm{C} 2$ domain rather than the full-length $\mathrm{C} 2$ domain encoded by exons 2 through 6 .

Experiments with the RSP5 yeast homolog of the NEDD4/NEDD4L family have demonstrated that it is involved in the ubiquitination and endocytosis of several membrane proteins. C2-less constructs of Rsp5 had no effect on the ubiquitination and internalization of the yeast alpha-factor receptor. However, the $\mathrm{C} 2$-less construct displayed defects in transport of fluid-phase markers through the endocytotic pathway to the vacuole, suggesting that Nedd4 proteins are internalized along with their ubiquitinated protein targets and that the $\mathrm{C} 2$ domain may also function postendocytosis (Dunn and Hicke 2001). This study also provided evidence that Rsp5 protein forms homomeric complexes, both in vitro and in vivo. Given these results, as well as the recent recognition that NEDD4L, rather than NEDD4, is the major regulator of $\mathrm{ENaC}$ in mammalian cells, the exact role of the NEDD4L $\mathrm{C} 2$ domain in both localization and activity of this protein requires further investigation.

Selective constraints on NEDD4L activity independent of $\mathrm{ENaC}$ interactions may be derived from evidence that NEDD4L is also involved in viral-associated processes of enveloped virus budding and viral latency. Recent evidence suggests that Nedd4 family proteins interact with coat proteins of enveloped viruses late in the process of viral budding, implicating ubiquitination in the function of viral protein late domains in retrovirus assembly (Hicke 2001; Patnaik et al. 2000; Strack et al. 2000; Vogt 2000). Using the late assembly domain of Rous sarcoma virus (RSV) Gag protein as a peptide probe on a chicken embryo expression library has resulted in the cloning of the $\mathrm{C} 2$ and WW domains of the chicken NEDD4L ortholog (Kikonyogo et al. 2001). In a human cell assay of RSV Gag budding, overexpression of the chiken NEDD4L WW domains resulted in dominant-negative inhibition of Gag budding, suggesting the overexpressed chicken NEDD4L WW domains inhibited Gag budding by competing with endogenous human NEDD4L. It has also been shown that the PY domain of $\mathrm{ENaC}$ can substitute for the RSV Gag late assembly domain in a virus-like particle assay in HeLa cells (Strack et al. 2000), implicating NEDD4L function in the budding of enveloped viruses containing PY motifs that include retroviruses. The protein produced from KIAA0439 has also been shown to form physiological complexes with the PY motifs in latent membrane protein 2A of Epstein-Barr virus (Winberg et al. 2000). It has been recently suggested that the molecular basis phenomenon of viral pseudotyping, the result of a mixed infection with two different enveloped viruses that results in phenotypic mixing of envelope proteins in the virus progeny, may be due to the sequestration of viral maturation components in lipid rafts (Pickl et al. 2001). As mentioned earlier, the $\mathrm{Ca}^{2+}$-dependent binding of Nedd4 to annexin XIIIb, mediated by the NEDD4 C2 domain, targets Nedd4 to lipid rafts in the apical surface of polarized MDCK epithelial cells (Plant et al. 2000). A plausible hypothesis is that sequestration of Nedd4 proteins in lipid rafts mediated by $\mathrm{Ca}^{2+}$-dependent binding interactions of the $\mathrm{C} 2$ domain may expose Nedd4 proteins to selective forces acting at the level of viral infectivity.

It has also been recently shown that $\mathrm{ENaC}$ activity is down-regulated after influenza virus infection of mouse tracheal epithelia, contributing to the accumulation of edema fluid in the airway (Kunzelmann et al. 2000; Matthay et al. 2002). This down-regulation is dependent on viral hemagglutinin binding to a cell surface receptor, which was shown to activate phospholipase $\mathrm{C}$ and protein kinase $\mathrm{C}$ (PKC). 
PKC inhibition of ENaC activity has also been demonstrated in vitro by coexpression of rat $\mathrm{ENaC}$ and rat $\mathrm{PKC}$ in Xenopus oocytes (Awayda et al. 1996). Regulation of ENaC activity by phosphorylation of mouse Nedd4-2 via aldosterone-dependent activation of serum and glucocorticoidregulated kinase has also been shown to control the cell surface density of ENaC (Debonneville et al. 2001b). Absorptive colonic epithelial cells are also a site for $\mathrm{Na}^{+}$ readsorption via $\mathrm{ENaC}$, and pathological conditions, such as infectious diarrhea, lead to alterations of $\mathrm{ENaC}$-mediated ion transport (Kunzelmann and Mall 2002). Given the importance of $\mathrm{ENaC}$ in maintaining fluid balance by $\mathrm{Na}^{+}$ transport in numerous epithelial tissues, and the effects of numerous viral and bacterial pathogens on ENaC activity, it can be postulated that these pathogens may be a source of selective pressure for alterations in $\mathrm{ENaC}$ regulation. The presence of NEDD4L transcripts that lack the conserved $\mathrm{C} 2$ domain may be an adaptation to regulating $\mathrm{ENaC}$ activity in response to a pathogenic challenge, and a putative effect of multiple forms of NEDD4L on orthostatic hypotension could be a secondary consequence of such selective adaptation.

In summary, a common variant in NEDD4L has been shown to affect splice site selection in a major transcript isoform expressed in kidney and adrenal gland. The variety of transcripts detected in human leading to either inclusion or exclusion of the $\mathrm{C} 2$ domain suggests that expression of different isoforms may lead to functional differences. Indeed, the presence of the $\mathrm{C} 2$ domain, by targeting such isoforms to cell membranes or membrane microdomains such as lipid rafts, may contribute to substrate specificity and the proposed interactions with $\mathrm{ENaC}$. Individuals ho- mozygous for the A allele variant are predicted to have a decrease in the amount of C2-domain NEDD4L produced from expression of isoform I. The common frequency of this allele suggests that any functional effect will be subtle, as small effects are expected for common variants in common disease. Variant 13 of NEDD4L is therefore a likely candidate single-nucleotide polymorphism for association with phenotypes relevant to orthostatic hypotension, hypertension, enveloped viral infections, and/or pathological conditions involving $\mathrm{Na}+$ absorption.

Acknowledgments List of HyperGEN participating institutions and principal staff: Network Center/University of Utah Field Center: Steven C. Hunt, Roger R. Williams (deceased), Hilary Coon, Paul N. Hopkins, Janet Hood, Nona Gallacher, Michael McGinty, Karen Nielsen, Lily Wu, Jan Skuppin. University of Alabama at Birmingham Field Center: Albert Oberman, Cora E. Lewis, Michael T. Weaver, Phillip Johnson, Randi Gilinson, Christie Oden. Boston University/ Framingham Field Center: R. Curtis Ellison, Richard H. Myers, Yuqing Zhang, Luc Djoussé, Jemma B. Wilk, Greta Lee Splansky. University of Minnesota Field Center: Donna Arnett, Aaron R. Folsom, Larry D. Atwood, Gregory Feitl, Jim Pankow, Barb Lux. University of North Carolina Field Center: Gerardo Heiss, Barry Freedman, Dee Posey, Kathryn Rose, Amy Haire. Data Coordinating Center, Washington University: D.C. Rao, Michael A. Province, Ingrid B. Borecki, Yuling Hong, Avril Adelman, Derek Morgan, Karen Schwander, David Lehner, Aldi Kraja, Stephe Mandel. Central Biochemistry Lab, University of Minnesota: John H. Eckfeldt, Ronald C. McGlennen, Michael Y. Tsai, Catherine Leiendecker-Foster, Greg Rynders. Molecular Genetics Laboratory, University of Utah: Mark Leppert, Steven C. Hunt, Jean-Marc Lalouel, Robert Weiss. National Heart, Lung, \& Blood Institute: Stephen Mockrin, Susan E. Old, Millicent Higgins (retired), Peter Savage, Cashell Jaquish.

This hypertension network is funded by cooperative agreements (U10) with NHLBI: HL54471, HL54472, HL-54473, HL54495, HL54496, HL54497, HL54509, HL54515.

\section{Appendix}

Appendix, Table 1. Oligonucleotide sequences for PCR amplification and sequencing of human NEDD4L

\begin{tabular}{|c|c|c|}
\hline NEDD4L exon & PCR primers $\left(5^{\prime}-3^{\prime}\right)$ & Sequencing primers $\left(5^{\prime}-3^{\prime}\right)$ \\
\hline 1 & $\begin{array}{l}\text { TCCGAGCAGAGCTCATGTAA } \\
\text { GGCCAGCAAGAGAGATAGGA }\end{array}$ & $\begin{array}{l}\text { AGAGGCATCGAAGTACACGC } \\
\text { AGGTTGCAGTGAGCCAAGAT } \\
\text { GCTGCCATAACAAAATACCCA } \\
\text { TCTAGCCCCTGGATGTGAC } \\
\text { ATATTGGATTAGGGCCCACC } \\
\text { TATGAACCTGCCACCTGGAC } \\
\text { GAAAGTGGCAGAGAGGAAGC } \\
\text { AGATGAATTAACAGCTCCAGCA }\end{array}$ \\
\hline 2 & $\begin{array}{l}\text { GAGGAGAGTTCCAGCCACTG } \\
\text { TGACTTCACGGTCAAGCAAG }\end{array}$ & $\begin{array}{l}\text { TGGCAGGAGTAATTGATCTTAATG } \\
\text { AGAGCCATAGTCCCACACTG }\end{array}$ \\
\hline $2 \mathrm{a}$ & $\begin{array}{l}\text { GCCTGCTTTCTTCACTTCTGA } \\
\text { GACTGCACCACCCTGAAGA }\end{array}$ & $\begin{array}{l}\text { GGTGTTGTTTTGTTGCAAGG } \\
\text { AAATGTTTTCACTGTGCCGC }\end{array}$ \\
\hline 3 & $\begin{array}{l}\text { GGCTGAGGGTGTCCATAGAA } \\
\text { CATGGAGATAGGCAAATTAAGACA }\end{array}$ & $\begin{array}{l}\text { TGTAAAGTCTGAACAAAATCTGTGTG } \\
\text { GCTGAGGCAGGAGAATCACT }\end{array}$ \\
\hline 4 & $\begin{array}{l}\text { TGGAGGCTTTATTGAAGATGC } \\
\text { GCTTTTCAGTCCTCCACAGG }\end{array}$ & $\begin{array}{l}\text { CTTGGTAGAATAATCATATCAATGCT } \\
\text { CGTCTCATAGAATTAAACCATTCTCA }\end{array}$ \\
\hline 5 & $\begin{array}{l}\text { GAGCTGATAGATGCTGTTGGC } \\
\text { TGCACTGAATTATAGTGTCACTTCTG }\end{array}$ & $\begin{array}{l}\text { TCTACAGTCATGAGAATGCCTTG } \\
\text { GCCTACCGTTCTGTATTCCC }\end{array}$ \\
\hline 6 & $\begin{array}{l}\text { GGCAGCGTGATTAGGTCTGT } \\
\text { AAGACCAGGTGCTGCTCACT }\end{array}$ & $\begin{array}{l}\text { CAGCTGTGCCCTCAAACC } \\
\text { GCCTGAGTGAAGGAGGTGTC }\end{array}$ \\
\hline $7,8,9$ & $\begin{array}{l}\text { AAACCCGGTGTGGATAGTGA } \\
\text { TCAGCTCATATTGAAAACAGCA }\end{array}$ & $\begin{array}{l}\text { CGTGGACTGTCAGGTACCAA } \\
\text { TCTAAAGAGAAATCTCTCCGAGG } \\
\text { GTGTCACCGACTGTGCAGAT } \\
\text { GTGACTCAAAGGCAATCGCT }\end{array}$ \\
\hline 10,11 & $\begin{array}{l}\text { GTTCTTCAGACCCCGGCT } \\
\text { TTGGATGAGCCACTTAAGCA }\end{array}$ & $\begin{array}{l}\text { GCAAATGGGCAGAGGACTT } \\
\text { CCACCTATACTTGTCAAATACGGC } \\
\text { TGATTCACATCATGGCCCTA } \\
\text { CCAAGAAAGTGTTAGTGGTATAAGG }\end{array}$ \\
\hline
\end{tabular}


Appendix, Table 1. Continued

\begin{tabular}{|c|c|c|}
\hline NEDD4L exon & PCR primers $\left(5^{\prime}-3^{\prime}\right)$ & Sequencing primers $\left(5^{\prime}-3^{\prime}\right)$ \\
\hline \multirow[t]{2}{*}{12} & TCAAGGGGAAGAACATGAGC & TTCTGAAAGTTTTGGTCTCCTC \\
\hline & TGTAAGGCAGGTGACGTGAG & TCAAAGTACAGATCACTGGAGCA \\
\hline \multirow[t]{2}{*}{13} & TGGAAACTGGTGATTCCTCC & TACCCAGGTCAAGGATGAGC \\
\hline & ATGCAATTCCTGTGGCTTCT & TGCACTTAACCAAAGCCTGA \\
\hline \multirow{6}{*}{$14,15,16$} & CCAAGCTGTGTTCACCTTCA & GGCAGCAACCCTTTACGTT \\
\hline & ACTTTGTGAGACGGGATCAA & GGCAGGGAAGAAGCTACACA \\
\hline & & TGGAAACTGGTGATTCCTCC \\
\hline & & ATGCAATTCCTGTGGCTTCT \\
\hline & & CTGAGTAGCTACCAAAGGATGG \\
\hline & & GAGCTTCCCAGGAGAAAAGG \\
\hline \multirow[t]{4}{*}{17,18} & AGTCAGCTCCTGGACTCTGG & CACTGCTGGGACTCTCTTCC \\
\hline & ATGAAGAACATGGCACCTCC & GCCACTTAAATTGTCACCTGC \\
\hline & & TTTTGAGCTAGCAGCCCATT \\
\hline & & GCACTGTTCACAGATTTTTGACT \\
\hline \multirow[t]{2}{*}{19} & TGCACATTAACTCACTTGGAAGA & AAATCCTTAAAAGAACAGGGGTTT \\
\hline & GATGGAAGAACCAATGGTGG & AGGAAGGGAGGGAATTTTGA \\
\hline \multirow[t]{4}{*}{20,21} & TCAATTCCTGAGCCCTCAAC & CACCCTGACTCATATTCTGACAA \\
\hline & AGCCTGGCAATGATGAAATC & TTGTGACTAGGGTTCTGAATTATTTT \\
\hline & & CATCGCTAGTGGATGCCG \\
\hline & & CCATGAACCCAATAGACAAGAA \\
\hline \multirow[t]{3}{*}{22,23} & ATTTGGCTGAACCATATGAAA & CTTCGTAGGTCAAAAACAGTCAA \\
\hline & CATGGTTCCAGGAAATGTGA & $\begin{array}{l}\text { TTGCTTTCACTAAAGTTATTCCAGA } \\
\text { TCTGGCCTGTCTACCCGC }\end{array}$ \\
\hline & & AGATCAATGAACTTTTCAAGCAA \\
\hline \multirow{2}{*}{24} & ACTGCTGGTTTGCCAGTCAT & TTTTGTAGACCAGTATGGCAGC \\
\hline & GTGACACCTGCATCCACAG & AACCGAGGCACAAATGAAAC \\
\hline \multirow[t]{4}{*}{25,26} & TTTCTGGAGTCTTGATGGGTG & GTTTCCTGATAAATGAATAGCAGAG \\
\hline & GGGACTGCGCTTCATCAT & TCTTAGTTGATATCCACATATTCCAA \\
\hline & & AAAGCATTTTAAAGCAGTTAAGCA \\
\hline & & GTACCGCCTGAAACTCCAAG \\
\hline \multirow[t]{4}{*}{27,28} & CACTGCCCAGATCGAACTTT & GCACTGACTCACAGCAGTGTT \\
\hline & CACAGATCAAAATATTTGTTGGAA & CAGCTCTGCTCAGTGGCCT \\
\hline & & CTAGAGGGGTAGGGAGGACG \\
\hline & & GGAGGACCAGTCCСТCAAAT \\
\hline \multirow[t]{4}{*}{29,30} & ATTATCTTAGGGCCACTGTTTG & TGGTGCCATCAGAGAGTTTG \\
\hline & TGACTTGGACACCATTTGGA & CGACCATATAAATGACCCTACAA \\
\hline & & GCCCAGCTGAGAGGCTGT \\
\hline & & CAGGTTGAGAGCTGCCTTATC \\
\hline \multirow[t]{10}{*}{31} & ATTGAGCCCTTGCTGTATGC & CTCCGAGATCTGCATCTGACT \\
\hline & CAAGATGACAGAAGAATCCCAG & TTAATTCCATTCATTGTCATTAGAAA \\
\hline & & ACCTGGTCCCAGCTTGAGTT \\
\hline & & TCGGATGAGAAATGGGAGTC \\
\hline & & CСATACTCAGAATGAAAAACTGGA \\
\hline & & TGAAGCATGCAACAGGTCAT \\
\hline & & TCAATTGTGAATCTGGCTGC \\
\hline & & GAAAAAGGAACCAACACTCAGC \\
\hline & & AAGTTGTGGTTTGGGGAGGT \\
\hline & & GGTTAGAATTGGATTTCTCCCTC \\
\hline
\end{tabular}

PCR, Polymerase chain reaction

Appendix, Table 2. Oligonucleotide sequences for RT-PCR and RACE experiments

\begin{tabular}{|c|c|}
\hline Location & Primer sequence \\
\hline \multicolumn{2}{|l|}{ RT-PCR } \\
\hline Exon 1 & ССАTTTCCAGAGAGGAACAACCGTG \\
\hline \multirow{2}{*}{ Exon 3} & GCGCCGGCTCCATGGCGACC \\
\hline & AGCAAGTTCTCTATTCTCATCCGCT \\
\hline \multicolumn{2}{|r|}{ (1) } \\
\hline \multirow[t]{2}{*}{ Exon 2} & CTGGCTCCAAAGATGTCCTTTTTGG \\
\hline & CGAGATCAATTCCAGAAACAAC \\
\hline \multirow[t]{2}{*}{ Exon $2 \mathrm{a}$} & GAGTGGGAGGTGCCGTGCTGG \\
\hline & GGAAGAGCTCGTCTGAAGTGG \\
\hline \multirow[t]{2}{*}{ Exon $2 c$} & GCTGCTGGAAATCTACCTTGG \\
\hline & GGCTGGAAAGTGTTCAGCTGG \\
\hline \multirow[t]{2}{*}{ Exon 3} & CCGCTACGTACAATGAAAGTTTCAC \\
\hline & AGCAAGTTCTCTATTCTATCCGCT \\
\hline
\end{tabular}

RT-PCR, Reverse transcription-polymerase chain reaction; RACE, rapid amplification of cDNA ends

\section{References}

Atwood LD, Samollow PB, Hixson JE, Stern MP, MacCluer JW (2001) Genome-wide linkage analysis of blood pressure in Mexican Americans. Genet Epidemiol 20:373-382

Awayda M, Ismailov I, Berdiev B, Fuller C, Benos D (1996) Protein kinase regulation of a cloned epithelial $\mathrm{Na}+$ channel. J Gen Physiol 108:49-65

Bala S, Peltomaki P (2001) CYCLIN D1 as a genetic modifier in hereditary nonpolyposis colorectal cancer. Cancer Res 61:6042-6045

Betticher DC, Thatcher N, Altermatt HJ, Hoban P, Ryder WD, Heighway J (1995) Alternate splicing produces a novel cyclin D1 transcript. Oncogene 11:1005-1011

Corvol P, Persu A, Gimenez-Roqueplo AP, Jeunemaitre X (1999) Seven lessons from two candidate genes in human essential hypertension: angiotensinogen and epithelial sodium channel. Hypertension 33:1324-1331

Debonneville C, Flores SY, Kamynina E, Plant PJ, Tauxe C, Thomas MA, Munster C, Chraibi A, Pratt JH, Horisberger JD, Pearce D, Loffing J, Staub O (2001a) Phosphorylation of Nedd4-2 by Sgk1 
regulates epithelial $\mathrm{Na}(+)$ channel cell surface expression. EMBO J 20:7052-7059

Debonneville C, Flores SY, Kamynina E, Plant PJ, Tauxe C, Thomas MA, Munster C, Chraibi A, Pratt JH, Horisberger J-D, Pearce D, Loffing J, Staub O (2001b) Phosphorylation of Nedd4-2 by Sgkl regulates epithelial $\mathrm{Na}+$ channel cell surface expression. EMBO J 20:7052-7059

DeStefano AL, Baldwin CT, Burzstyn M, Gavras I, Handy DE, Joost O, Martel T, Nicolaou M, Schwartz F, Streeten DH, Farrer LA, Gavras H (1998) Autosomal dominant orthostatic hypotensive disorder maps to chromosome 18q. Am J Hum Genet 63:1425-1430

Dunn R, Hicke L (2001) Domains of the Rsp5 ubiquitin-protein ligase required for receptor-mediated and fluid-phase endocytosis. Mol Biol Cell 12:421-435

Ewing B, Hillier L, Wendl MC, Green P (1998) Base-calling of automated sequencer traces using phred. I. Accuracy assessment. Genome Res 8:175-185

Harvey KF, Dinudom A, Cook DI, Kumar S (2001a) The Nedd4-like protein KIAA0439 is a potential regulator of the epithelial sodium channel. J Biol Chem 276:8597-8601

Harvey KF, Dinudom A, Cook DI, Kumar S (2001b) The Nedd4-like protein KIAA0439 is a potential regulator of the epithelial sodium channel. J Biol Chem 276:8597-8601

Hicke L (2001) A new ticket for entry into budding vesicles-ubiquitin. Cell 106:527-530

Ikonen E (2001) Roles of lipid rafts in membrane transport. Curr Opin Cell Biol 13:470-477

Kamynina E, Debonneville C, Bens M, Vandewalle A, Staub O (2001a) A novel mouse Nedd4 protein suppresses the activity of the epithelial $\mathrm{Na}+$ channel. FASEB J 15:204-214

Kamynina E, Tauxe C, Staub O (2001b) Distinct characteristics of two human Nedd4 proteins with respect to epithelial $\mathrm{Na}(+)$ channel regulation. Am J Physiol Renal Physiol 281:F469-477

Kikonyogo A, Bouamr F, Vana ML, Xiang Y, Aiyar A, Carter C, Leis J (2001) Proteins related to the Nedd4 family of ubiquitin protein ligases interact with the $\mathrm{L}$ domain of Rous sarcoma virus and are required for gag budding from cells. Proc Natl Acad Sci USA 98:11199-11204

Kong S, Amos CI, Luthra R, Lynch PM, Levin B, Frazier ML (2000) Effects of cyclin D1 polymorphism on age of onset of hereditary nonpolyposis colorectal cancer. Cancer Res 60:249-252

Kristjansson K, Manolescu A, Kristinsson A, Hardarson T, Knudsen $\mathrm{H}$, Ingason S, Thorleifsson G, Frigge ML, Kong A, Gulcher JR, Stefansson K (2002) Linkage of essential hypertension to chromosome 18q. Hypertension 39:1044-1049

Kunzelmann K, Beesley AH, King NJ, Karupiah G, Young JA, Cook DI (2000) From the cover: infleuenza virus inhibits amiloridesensitive $\mathrm{Na}+$ channels in respiratory epithelia. Proc Natl Acad Sci USA 97:10282-10287

Kunzelmann K, Mall M (2002) Electrolyte transport in the mammalian colon: mechanisms and implications for disease. Physiol Rev 82:245289

Lemmon SK, Traub LM (2000) Sorting in the endosomal system in yeast and animal cells. Curr Opin Cell Biol 12:457-466

Liddle GW, Bledsoe T, Coppage WS Jr (1963) A familial renal disorder simulating primary aldosteronism but with negligible aldosterone secretion. Trans Assoc Am Physicians 76:199-213

Lifton PR, Gharavi AG, Geller DS (2001) Molecular mechanisms of human hypertension. Cell 104:545-556

Luft FC (2000) Molecular genetics of human hypertension. Curr Opin Nephrol Hypertens 9:259-266

Makalowski W, Zhang J, Boguski MS (1996) Comparative analysis of 1196 orthologous mouse and human full-length mRNA and protein sequences. Genome Res 6:846-857

Matthay MA, Folkesson HG, Clerici C (2002) Lung epithelial fluid transport and the resolution of pulmonary edema. Physiol Rev 82:569-600
Nakai K, Sakamoto H (1994) Construction of a novel database containing aberrant splicing mutations of mammalian genes. Gene 141:171-177

Nickerson DA, Tobe VO, Taylor SL (1997) PolyPhred: automating the detection and genotyping of single nucleotide substitutions using fluorescence-based resequencing. Nucleic Acids Res 25:27452751

Pankow JS, Rose KM, Oberman A, Hunt SC, Atwood LD, Djousse L, Province MA, Rao DC (2000) Possible locus on chronosome 18q influencing postural systolic blood pressure changes. Hypertension $36: 471-476$

Patnaik A, Chau V, Wills JW (2000) Ubiquitin is part of the retrovirus budding machinery. Proc Natl Acad Sci USA 97:13069-13074

Pickl WF, Pimentel-Muinos FX, Seed B (2001) Lipid rafts and pseudotyping. J Virol 75:7175-7183

Plant PJ, Yeger H, Staub O, Howard P, Rotin D (1997) The C2 domain of the ubiquitin protein ligase Nedd 4 mediates $\mathrm{Ca} 2+$-dependent plasma membrane localization. J Biol Chem 272:32329-32336

Plant PJ, Lafont F, Lecat S, Verkade P, Simons K, Rotin D (2000) Apical membrane targeting of Nedd4 is mediated by an association of its C2 domain with annexin XIIIb. J Cell Biol 149:1473-1484

Rebhun JF, Pratt JH (1998) Molecular cloning of Nedd4 from Xenopus laevis. DNA Seq 9:295-306

Rogan PK, Faux BM, Schneider TD (1998) Information analysis of human splice site mutations. Hum Mutat 12:153-171

Schild L, Canessa CM, Shimkets RA, Gautschi I, Lifton RP, Rossier BC (1995) A mutation in the epithelial sodium channel causing Liddle disease increases channel activity in the Xenopus laevis oocyte expression system. Proc Natl Acad Sci USA 92:56995703

Schultz J, Copley RR, Doerks T, Ponting CP, Bork P (2000) SMART: a web-based tool for the study of genetically mobile domains. Nucleic Acids Res 28:231-234

Shimkets RA, Warnock DG, Bositis CM, Nelson-Williams C, Hansson JH, Schambelan M, Gill JR Jr, Ulick S, Milora RV, Findling JW, Canessa CM, Rossier BC, Lifton RP (1994) Liddle's syndrome: heritable human hypertension caused by mutations in the beta subunit of the epithelial sodium channel. Cell 79:407-414

Snyder PM, Olson DR, McDonald FJ, Bucher DB (2001) Multiple WW domains, but not the $\mathrm{C} 2$ domain, are required for inhibition of the epithelial $\mathrm{Na}+$ channel by human Nedd4. J Biol Chem 276:28321-28326

Snyder PM, Olson DR, Thomas BC (2002) Serum and glucocorticoidregulated kinase modulates Nedd4-2-mediated inhibition of the epithelial Na+ channel. J Biol Chem 277:5-8

Staub O, Dho S, Henry P, Correa J, Ishikawa T, McGlade J, Rotin D (1996) WW domains of Nedd4 bind to the proline-rich PY motifs in the epithelial $\mathrm{Na}+$ channel delected in Liddle's syndrome. EMBO J 15:2371-2380

Stephens RM, Schneider TD (1992) Features of spliceosome evolution and function inferred from an analysis of the information at human splice sites. J Mol Biol 228:1124-1136

Strack B, Calistri A, Accola MA, Palu G, Gottlinger HG (2000) A role for ubiquitin ligase recuritment in retrovirus release. Proc Natl Acad Sci USA 97:13063-13068

Vogt VM (2000) Ubiquitin in retrovirus assembly: actor or bystander? Proc Natl Acad Sci USA 97:12945-12947

Williams RR, Rao DC, Ellison RC, Arnett DK, Heiss G, Oberman A, Eckfeldt JH, Leppert MF, Province MA, Mockrin SC, Hunt SC (2000) NHLBI family blood pressure program: methodology and recruitment in the HyperGEN network. Hypertension genetic epidemiology network. Ann epidemiol 10:389-400

Winberg G, Matskova L, Chen F, Plant P, Rotin D, Gish G, Ingham R, Ernberg I, Pawson T (2000) Latent membrane protein 2A of Epstein-Barr virus binds WW domain E3 protein-ubiquitin ligases that ubiquitinate B-cell tyrosine kinases. Mol Cell Biol 20:85268535 